\title{
Intersections
}

Canadian Journal of Music

Revue canadienne de musique

\section{Seeds for a Mature Compositional Style: An Analysis of Melody, Musical Layers, and Signals in Claude Vivier's Chants}

\section{Brian Harman}

Volume 33, numéro 2, 2013

Musical Perspectives, People, and Places: Essays in Honour of Carl Morey

URI : https://id.erudit.org/iderudit/1032700ar

DOI : https://doi.org/10.7202/1032700ar

Aller au sommaire du numéro

Éditeur(s)

Canadian University Music Society / Société de musique des universités canadiennes

ISSN

1911-0146 (imprimé)

1918-512X (numérique)

Découvrir la revue

Citer cet article

Harman, B. (2013). Seeds for a Mature Compositional Style: An Analysis of Melody, Musical Layers, and Signals in Claude Vivier's Chants. Intersections, 33(2), 141-153. https://doi.org/10.7202/1032700ar
Résumé de l'article

L'oeuvre de Claude Vivier intitulée Chants est considérée par beaucoup comme étant sa première oeuvre importante. Toutefois, très peu d'études ont tenté de déterminer quelles techniques et quelles idées se sont transmises de cette oeuvre à ses compositions plus tardives. Cet article présente une analyse approfondie de Chants du point de vue de l'organisation des hauteurs et de l'importance de la mélodie principale dans toute la composition. Cette analyse est suivie d'un examen de la manipulation des différentes couches musicales ainsi que de l'utilisation de certains procédés musicaux pour annoncer les changements formels de l'oeuvre. L'auteur avance que ces caractéristiques se retrouvent de façon importante dans les oeuvres ultérieures de Vivier, ce qui montre que Chants a bien été une oeuvre cruciale dans le développement du compositeur.
Copyright @ Canadian University Music Society / Société de musique des universités canadiennes, 2013
Ce document est protégé par la loi sur le droit d'auteur. L’utilisation des services d'Érudit (y compris la reproduction) est assujettie à sa politique d'utilisation que vous pouvez consulter en ligne.

https://apropos.erudit.org/fr/usagers/politique-dutilisation/ 


\section{SEEDS FOR A MATURE COMPOSITIONAL STYLE: AN ANALYSIS OF MELODY, MUSICAL LAYERS, AND SIGNALS IN CLAUDE VIVIER'S CHANTS}

\section{Brian Harman}

\section{INTRODUCTION}

Composed in 1972 and 1973, Chants is acknowledged by Claude Vivier (19481983) as one of his first mature works (Vivier and Robert 1991, 55). It differs significantly from his previous works in its intensely personal nature. Vivier described this period of his compositional life as one of purification, when he was trying to rid himself of all influence and return to a child-like state of composing; he went so far as to give Chants the preliminary title Reinigung (purification). He further explains in his program note for the piece that he was trying to inject some of his everyday life into his music (Vivier 1978).

Vivier wrote the text for the work himself. Most of it is based on Latin religious text-some of which is spoken backwards-while other parts of the work are written in an invented language. Vivier's inspiration was a vivid dream about both a ritual of death and a child that is unable to express itself (Vivier 1978); as a result, the text refers extensively to the requiem and to childhood. The mother is an important figure in the piece: the word Maria is used extensively, as is mamouchka, the Polish word for "mommy." Vivier was an orphan who never knew his mother, and so this theme arises frequently in his compositions.

Written for two sopranos, two mezzo-sopranos, and three altos, the score is split into two choirs (each choir containing one of each voice type), as well as a seventh alto voice that sings only in the fifth section of the piece. This alto part represents Vivier's own voice and is described by the composer as a kind of alter ego who always wanted to say something important but forgot what that might be (Vivier 1978). In this analysis, voices 1 through 3 will be referred to as choir 1 and voices 4 through 6 will be referred to as choir 2 .

The piece is divided into eight sections: I: "Réveil des Trois Mortes," 1-8; II: "L’Enfant et la Mort," 9-14; III: "Musique Étrange," 15-22; IV: "Théâtre," 23-27, V: "Grand Tutti," 28-37; VI: "Contrepoint, Appels," 38-60; VII: "Souvenirs," 61-67; and VIII: "Finale," 67-68 (Vivier 1978).

The following analysis of Chants will focus initially on pitch organization and the influence of the principal melody on the work as a whole, describing in detail points of symmetry, the expansion and contraction of musical cells, and large-scale pitch organization. Then the article will focus on two specific compositional techniques as they appear throughout the work: musical layers 
and the evolving relationship between them, and the use of signals to indicate change in discourse, especially musical processes that act as signals. Despite the fact that Chants is a very early work, from a period of the composer's output that has received scant analysis, ${ }^{1}$ it is clear that the pitch organization and compositional techniques utilized here both inform and have ramifications for Vivier's late compositional style.

\section{Pitch Organization and the Influence of Melody}

\section{Local Pitch Organization}

Vivier wrote that in Chants "all [material] had to come from one melodic cell" (Vivier 1978). ${ }^{2}$ In fact, melody is a guiding musical element in much of the composer's output, acting as source material for decisions regarding pitch, rhythm, and structure. Chants is an excellent example of this tendency-its initial melody generates extensive melodic and harmonic material for the work and eventually gives birth to two other melodies.

Melody 1 is presented in voice 1 over the first five pages of the score, with extensive ornamentation and repetition of individual pitches and melodic cells, and is then sung more succinctly in the same voice at the beginning of section II (9). The pitches of the melody form an incomplete octatonic scale (or Messiaen's second mode of limited transposition), as shown in example 1; C is the only missing pitch. The basic elements of the melody-its interval content, the set classes found therein, and its mode-become the basic elements from which the entire piece is built.

Melody 1 begins with B-flat, the tonal centre for the first three sections of the work. The minor third and major sixth-inversionally complementary intervals-are stressed, with four appearances of the minor third as the melody unfolds. Melodically, the minor third remains important throughout the piece; to give but one initial example, the entrance of voice 4 at the top of the second choir features this interval. Juxtaposed against the minor third is the major third, presented at the end of the melody-another interval that is reinforced throughout the work and in the large scale. Harmonically, the pairing of B-flat and D-flat twice in melody 1 foreshadows the B-flat minor triad that is central to the work.

Most of the harmonic material for the piece is derived directly from melody 1. The most important set class in the work is [014], found in several segments of the melody, including its first three and last three pitches. Other recurring harmonic trichords found in the melody are [013], [025], [016], [026], and [036] (the diminished triad). Vivier already uses the [014] set class vertically at measure 3 in choir 1 , the first held chord of the piece. The diminished triad is used more often in Chants as a tetrachord, with an added dissonant pitch. For

1 The only published analysis of Chants is Martine Rhéaume's 2008 article, which discusses the work in the context of an evolution of the composer's melodic style of composition, using a paradigmatic methodology. While it reveals some interesting tendencies with regards to melodic "formulas" in Vivier's early writing, the analysis is far from exhaustive.

2 Translation by the author. "Tout devait partir d'une cellule mélodique." 


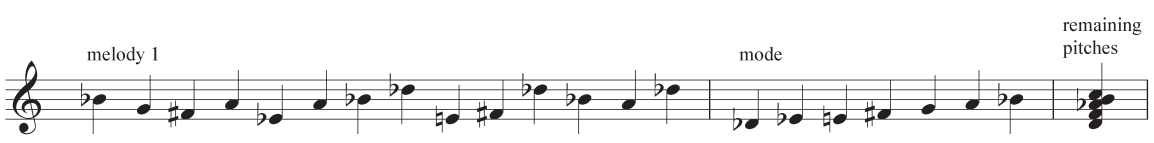

Example 1: Melody 1 and its mode

example, [0236] can be found between the second and fifth pitches of the melody. This tendency to blur a chord - that is, adding to any traditional triad a minor second next to one of its pitches-is apparent in many of Vivier's works, especially early in his output. ${ }^{3}$ This diminished triad with a blurring note, whether in [0236] form or others such as [0147], is seen throughout Chants and will be referred to as the diminished blur chord.

The influence of melody 1 on the fabric of the work is made clear in the composition's first five pages: as voice 1 states the melody as described above, voices 2 and 3 sing fragments of it, and the first choir as a whole remains exclusively within the mode established by the melody. The only exceptions are a few ornamental pitches: for example, the $B$ in voice 1 and the $D$ in voice 3 , both on page 2, first and second measures, are ornamental pitches outside the mode, decorating the sustained chords.

While most of the chords heard in choir 2 in the first part of section I are derived from melody 1 , the second choir-unlike the first-deviates frequently from the mode of melody 1 . This distinction creates two musical layers, with the differences between them strengthened by their contrasting textures: the first choir sings contrapuntal lines while the second sings homophonic chords. The three statements of "a-i-ram" (Maria spelled backwards) in the second choir act as commentary on the first choir's polyphony. The first two instances settle on a first-inversion B-flat minor chord, contrasting with the more dissonant harmonic language in choir 1 . All other chords in the second choir up to the end of page 5 are derived from melody 1, except for the [015] chord found at the beginning of page 4. [015] is important to melody 2 and is an expansion of the [014] cell found at the beginning of melody 1.

As voice 1 moves chromatically up to the last note of the melody on page 5 , the first choir breaks free of the mode imposed on it up until now. Voice 3 follows with a repeated $\mathrm{F}$ extraneous to the mode and, in the last bar of page 5 , sings a simultaneous inversion of the line in voice 1, introducing Vivier's symmetrical pitch techniques and further introducing pitches outside the mode.

The first choir introduces new pitch material in the second part of section I. First, on pages 6 and 7 , the pitches in voice 1 comprise a combination of two chromatic clusters: C to D-sharp and F-sharp to B-flat. Chromatic clusters of varying sizes-both in their compact form and with wider spacings-are found throughout the piece, usually in contrapuntal textures, and are expanded and contracted in various ways that will be described below. Second, melody 2 is introduced inconspicuously in voice 3 . It is more loosely defined than melody 1 , since its pitches are sometimes reordered and slightly altered, but it is always

3 Especially noteworthy is the extended use of this technique at the opening of Shiraz, for solo piano. Vivier writes a repeatedly struck $\mathrm{C}$ major/minor chord using the same blurring technique. 
characterized by the [0145] cell—an expansion of the [0134] tetrachord from melody 1 . As such, melody 2 is an outgrowth of melody 1, reinforcing Vivier's comment about the importance of one melody in this work. The initial version of melody 2, presented in voice 3 on pages 6 and 7 , is illustrated in example 2 .

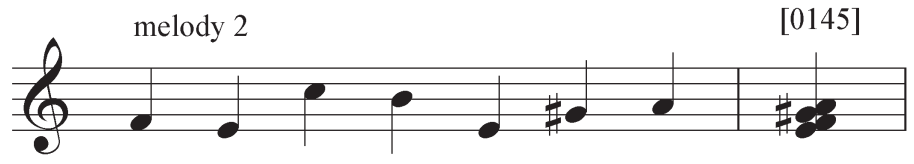

Example 2: Melody 2 and the [0145] cell

The opening of section II brings back the principal melody in voice 1, but with a contrapuntal accompaniment that fills the remainder of the chromatic spectrum; voices 2 and 3 each sing pitches from a different diminished blur tetrachord. In the second measure of page 10, the first choir begins a progression from a diminished triad inwards to the pitch B-flat, reinforcing this pitch as the tonal centre. As soon as the three voices reach this common note, a chromatic cluster is formed, symmetrical around B-flat: voice 1 moves up to Bnatural and voice 3 down to $A$. The $A$ and $B$ of this small cluster are sustained until the beginning of section III (15), where the B-flat reappears and is accompanied by spoken text.

The end of section III centres again on the B-flat minor chord, this time in oscillation with the A minor chord a semitone lower. As illustrated in example 3 , the combination of these two chords generates the [0145] cell that is important to melody 2. The musical processes that govern the end of this section will be discussed in detail below.

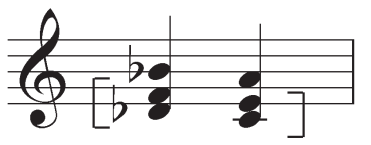

[0145]

Example 3: Oscillating minor triads in section III

The opening measures of section IV emphasize the previously avoided pitches F, G-sharp, B, C, and D in the first choir-the five pitches extraneous to the mode of melody 1 -giving a fresh quality to this music. All three voices of choir 1 begin on F-the dominant of B-flat-and the minor third continues to exert influence; for example, voice 1 begins with a soaring minor tenth leap upwards. The following wave-like figures in choir 1 feature the defining cells from Chants' opening, namely [025] and [0147], as illustrated in example 4.

Chromatic clusters return in section V of the work, where the composer initiates a large-scale process of contracting cluster size. The tritone-wide chromatic cluster in choir 1 on page 29-from G-sharp to D (with voice 2 singing $B$, the point of symmetry) - is gradually compressed at each return of this 


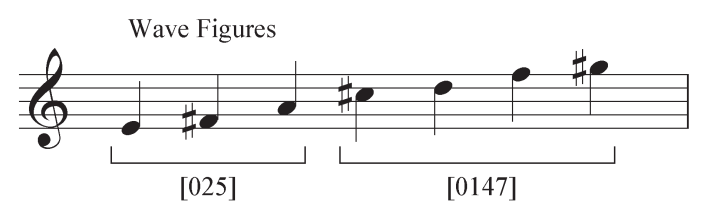

Example 4: Wave-like figures in section IV (choir 1)

particular texture featuring rhythmic counterpoint: at the beginning of page 30, the first choir chromatically fills A to C-sharp, then A to C at the end of page 31. Finally, as the climax of the piece approaches (beginning at 33), an even smaller major second-wide cluster in both choirs gradually contracts to B-flat, its point of symmetry. Example 5 summarizes this gradual cluster contraction from a tritone to a unison B-flat just before the climax of section V. The only voice to skirt this trend and effectively create its own musical layer is the seventh voice.

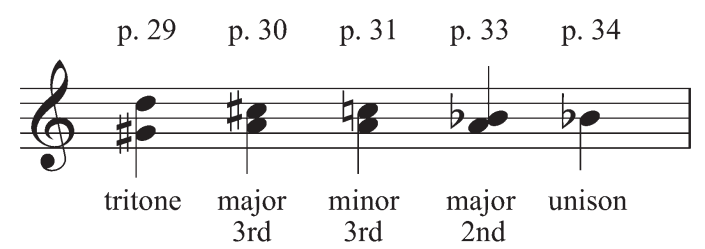

Example 5: Large-scale contraction of cluster size in section $\mathrm{V}$

Returning to the middle of section IV on page 25 , there is a shift in emphasis to the pitch E-a tritone away from the established centre B-flat-and a more vertical representation of melody 2 in the fifth measure of the page (voices 1 through 3). This appearance of the melody is at the same transposition level as its initial presentation, but now it features $\mathrm{C}$-sharp instead of C-natural-another upwards expansion-and omits the pitch $\mathrm{B}$. The texture here has each of the three voices oscillate on a major third, emphasizing this interval's importance and its expansion from the pivotal minor third.

The music on pages 32 and 33 further underlines the important tritone relationship between B-flat and E. Vivier superimposes the two choirs singing simultaneous chord progressions that use the same succession of pitch sets but transposed at the tritone. Rhythmically, the choirs do not line up-one choir moves ahead in the progression while the other briefly sustains its chord, and vice versa-until the beginning of page 33, where the first and second choirs simultaneously sing B-flat minor and E minor chords respectively. This passage clearly demonstrates the musical and poetic relationship that Vivier aimed to create between the two choirs; in his notes about Chants, Vivier described voices 4 through 6 as "three shadows or, if you like, three memories of women" (Vivier 1978). ${ }^{4}$ The second choir sings the first choir's music transposed at the

4 “trois ombres ou, si l'on veut, trois souvenirs des femmes" (author's translation) 
tritone, creating a simultaneous shadow of the first choir. These two progressions are illustrated in example 6.

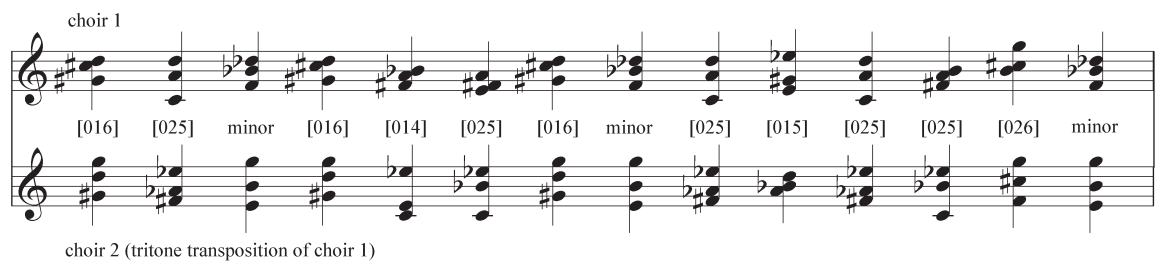

Example 6: Tritone-related progressions in choirs 1 and 2

Section VI (38) begins with a unison C in the second choir, a pitch not heard since the middle of page 35 in order to emphasize this moment. Choir 2 supports the first choir's ornate counterpoint with sustained unisons, dyads, and trichords. From the beginning of this section to its middle, the composer gradually expands the size of these supporting chords, from a unison C, to a major third on page 38 , to a perfect fourth on page 39 , to a perfect fifth on page 41 , and finally to a minor sixth on page 45 . This process is illustrated in example 7. A further example of expansion can be found in voice 2 slightly later in section VI, beginning on page 44. This voice initially oscillates between B-flat, C, and $\mathrm{D}$, a [024] cell. When this oscillating gesture returns on page 50 , the cell is expanded to [048], and later to [05T] on page 54 , as shown in example 8.

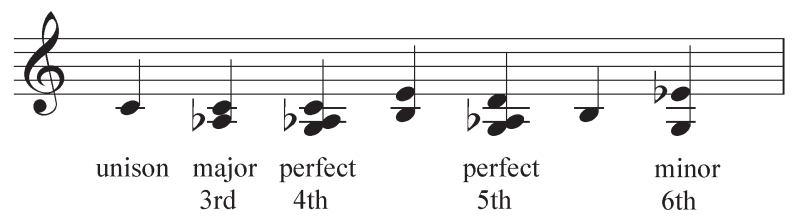

Example 7: Expansion of pitch cells in section VI (choir 2)

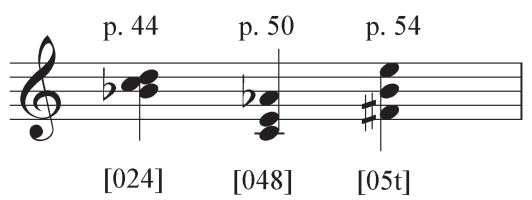

Example 8: Expansion of pitch cells in section VI (voice 2)

The first choir's counterpoint in section VI is florid and rhythmically complex, but the pitch content of this polyphony is carefully controlled in order to maintain contrasting layers between the two choirs. It is not until the end of section VI that there are any simultaneous common pitches between the two choirs. A few examples will illustrate how carefully Vivier maintains these layers. From the middle of page 41 to the beginning of page 45 , voice 1 sings the pitches E, F, G-sharp, B, and C-the original pitches from melody 2 minus Abut does not sing E until the end of page 41, when the second choir has moved 
on from sustaining $\mathrm{E}$ within a sustained dyad. After this change, voice 1 avoids G-sharp, since the second choir is now singing this pitch, and from the middle of page 43 it does not sing $B$, where the second choir is singing this pitch in unison. From the middle of page 45 , voice 2 sings the pitches B-flat, C, and D, but when the second choir begins to sustain a $C$ on page 47 , voice 2 avoids $C$ altogether. Not until page 59, two measures before a distinct change in texture, does a common pitch between the two choirs appear: voice 1 sings a $\mathrm{C}$ that is also part of the second choir's trichord.

Beginning on page 54, amidst this dense counterpoint, Vivier introduces melody 3 in voice 1 . It begins on B-flat, like melody 1 , and is based on a transposed version of the mode of melody 1 , as illustrated in example 9. Like melody 1, it uses all but one pitch (F-sharp) from an octatonic scale, but adds two pitches extraneous to that scale: B and G-sharp. These additional pitches are each a major third away from the point of symmetry of the ambitus of this melody, E and D-sharp: B is a major third below D-sharp, and G-sharp a major third above E. This nine-note melodic mode can be seen as an outgrowth of the work's initial mode, just as the important pitch cell [0145] of melody 2 is an expansion of the [0134] cell from melody 1.

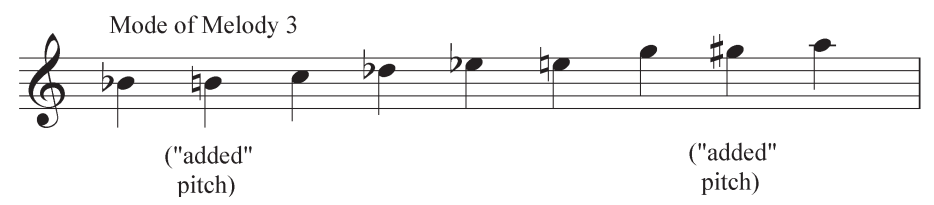

Example 9: Mode of melody 3

To end section VI (59-60), Vivier employs the untransposed [0145] cell from melody 2, but with the pitch A now down an octave and acting as a drone in the five lower voices, supporting the florid melody in voice 1 . This new texture creates a dramatic break, providing respite from the active polyphony leading up to this moment.

In section VII, "Souvenirs," Vivier presents two "memories" from earlier in the work-both in the second choir, reinforcing this choir as the "memory" choir. First, beginning in the fourth measure of page 61, choir 2 reintroduces music sung in section V (30) by the first choir with some slight durational alterations, as if this musical memory were slightly inaccurate. Melody 1 then returns on page 63 in its most concise form (originally at 9). It is transposed up a perfect fourth along with its original contrapuntal accompaniment, this time clearly "recalled" with no durational changes.

After an emphasis on the pitch B at the beginning of section VII-all three voices of the first choir begin on this pitch and eventually sustain it while the second choir sings its first memory-the B + E perfect fourth dyad that was introduced in section VI returns on page 62, begging for a resolution to $\mathrm{B}+$ D-sharp. Vivier does not offer this resolution until just prior to section VIII, the final section of the work. Preceding this, the B + E dyad is combined with pitches that have been emphasized throughout the work: a sustained B-flat in 
voice 6 during the second choir's recollection of melody 1 , and a sustained $\mathrm{F}$ major triad on page 65. Vivier then composes an extended solo for voice 3 over the sustained B + E dyad, generating E major harmony. This contrasts with the E minor harmony found throughout the work and mirrors the expansion from minor third to major third in melody 1. For an illustration of these final progressions, see the piece's large-scale pitch organization in example 10.

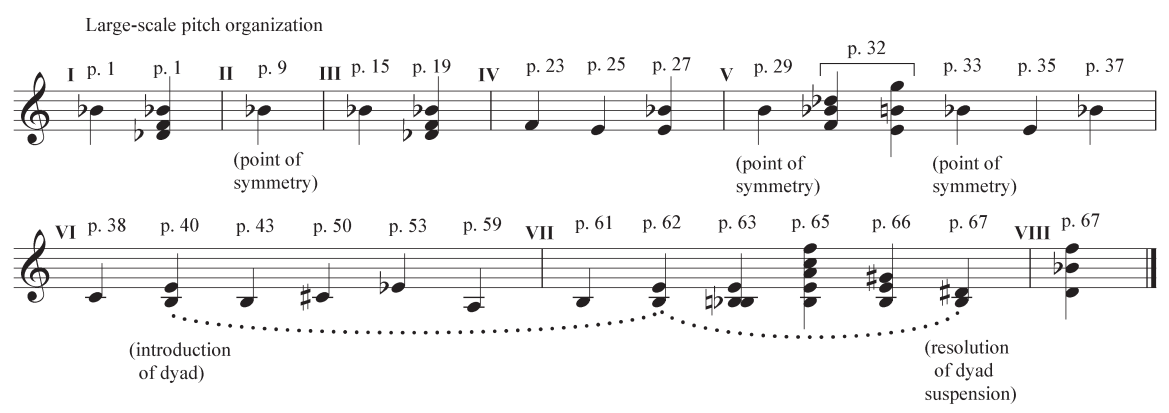

Example 10: Large-scale pitch organization in Chants

The work's final section is a series of sustained trichords interrupted by brief punctuating chords. All harmonies are based on harmonic cells discussed above, and horizontal lines within each voice part follow patterns of intervals established in melody 1 . Noteworthy is the sustained B-flat major chord near the beginning of this section, contrasting the B-flat minor chord found throughout the work's first half and, again, reflecting the expansion from minor to major third in melody 1.

\section{Large-Scale Pitch Organization}

The tonal centre of Chants is B-flat, because of, among other reasons, the emphasis on this pitch in melodies 1 and 3 , the foundational B-flat minor and major triads, and the frequent use of B-flat as a point of symmetry. A tritone away, $\mathrm{E}$ is introduced in section IV ( 25 and 26 ) as a pedal tone after a brief emphasis on $\mathrm{F}$ at the beginning of that section. B-flat and $\mathrm{E}$ are juxtaposed at a close distance on page 27, where a B-flat minor triad is followed twice by a sustained $\mathrm{E}$. As described above, section $\mathrm{V}$ features the superimposition of tritone-related progressions, including B-flat minor and $\mathrm{E}$ minor chords. This is followed by a near-tutti B-flat approaching the climax (33-34), before three pages of chords that share $\mathrm{E}$ as a common note (with the exception of one chord). At the very end of the section, a solo in voice 3 again emphasizes B-flat.

Other observations about large-scale pitch organization underline the importance of these pitches, of chromatic clusters, and of tritone relationships. Choir 2's slow progression of sustained unisons in section VI first fills in a small chromatic cluster, moving from C (38) to B (43-45) to C-sharp (50), and later outlines another tritone, from E-flat (53-56) to A (59-60). In section VII Vivier juxtaposes the B + E dyad with more tritone-related pitches: a sustained $\mathrm{B}$-flat (63, voice 6) - a tritone away from $\mathrm{E}$-and an $\mathrm{F}$ major triad (page 65, 
choir II) - a tritone away from B. A passage in E major then leads to the resolution of this dyad to a major third. Finally, Vivier writes a sustained B-flat major triad in section VIII, recalling this important pitch centre one last time, now in the context of a major triad. Example 10 gives an overview of the work's pitch organization.

The prominence of tritone relationships is influenced by melody 1 , where this interval appears twice between successive pitches. The importance of the $\mathrm{B}$-flat $+\mathrm{E}$ tritone has been elucidated; less obvious, perhaps, is the tritone relationship between the emphasized $\mathrm{F}$ at the beginning of section IV and the $\mathrm{B}$ supporting the dyad at the end of the work. B is also the point of symmetry for a chromatic cluster on page 29.

\section{The Use of Musical Layers and Signals for Change}

The second part of this article will closely examine two specific techniques Vivier employs in Chants: the use of superimposed musical layers and the interactions that occur between these layers, and the use of signals to indicate change in the musical discourse, especially processes that act as signals. First, Vivier's handling of musical layers is especially relevant here, because his notes were explicit that the vocal ensemble consists of two distinct choirs. The composer creates diverse relationships between the choirs in the work, from simple alignment to influence between layers and role reversal. Second, Vivier is known for his use of signals-especially percussive signals-to clarify structure in his music. A simple example found in Chants is the woodblock strike on page 5, occurring at the exact moment that voice 1 breaks out of melody i's mode. The following analysis will show that the composer also employs more subtle signals-often involving musical processes-in collaboration with moments of change in his music.

As described above, the beginning of the work consists of two layers: the first choir sings contrapuntal music above a more static, homophonic texture in the second choir. The distinction between the layers is reinforced by the contrast between the near-octatonic mode used in the first choir and the frequent appearance of the B-flat minor chord in the second. The layers remain distinct until the end of section I, where the two choirs momentarily sing a B-flat minor chord together before the first choir ascends chromatically and homophonically to a high point.

The termination and alignment of two musical processes signals this merging of musical layers. Beginning on page 6 , the second choir sings a progression of chords, and a woodblock strike occurs after each new chord at a distance of either $0,1,2$, or 3 sixteenth notes. This distance follows a repeated increasing, then decreasing, trend, and creates a palindrome: $0,1,2,3,2,1,0,1,2,3,2$, 1, o. (The italicized 2 represents a strike on the woodblock that is not present in the score, the omission of which may be an oversight, since the process is otherwise rigorously observed.) This process ends at the appearance of the Bflat minor chord that aligns the two choirs. The second process is found in the durations of choir 2's sustained chords. In eighth notes, the durations follow a 
decreasing, then increasing, trend, again creating a palindrome: $7,6,5,4,3,2,1$, $1,2,3,4,5,6,7$. This last chord is the same B-flat triad that brings together the two choirs; thus, the termination and alignment of these two processes, as well as the B-flat chord itself, act as signals for change, bringing together the two layers and closing section I.

The second choir is then absent until the end of section III, while the first choir splits into two layers. At page 13, voice 2 speaks with indefinite pitch about what was told to her as a child about death, while voices 1 and 3 provide a static background using the syllables "ri-a" from the word Maria. Suddenly, at page 15, these roles are reversed: voices 1 and 3 move on from religious text to mostly nonsense text, while voice 1 changes from "childhood" text to religious text on a sustained B-flat. This role reversal technique is employed in various guises throughout the work, a few more of which will be discussed below.

The second choir returns on page 19 with an oscillation between B-flat minor and A minor chords. With this entrance, choir 2 instigates a process in the first choir: voices 1 and 3, previously rhythmically distinct, begin to come together and eventually sing in rhythmic unison in the first measure of page 21. This process begins at the exact moment of the second choir's entry.

At its entrance, the second choir begins a process of its own. Using the three syllables of the word populus, it sings a repeated pattern of one quarter note's duration of sixteenth notes, one of triplet eighth notes, and one of eighth notes, with a gradual change in the number of sixteenth notes at each repetition creating the palindrome $4,3,2,1,2,3,4$ before the section ends with a single quarter note. The first choir begins a similar ritardando process on page 21, but using quintuplet sixteenth notes in addition to the values seen in choir 2 . (This process is repeated unchanged, unlike the process in the second choir.) The rhythmic values in the two choirs align for the last repetition of this slowing cell at the same time as the palindrome is completed in the second choir, and section III ends. Once again, Vivier uses the alignment and completion of musical processes to signal the end of a section of music.

Role reversal is further employed in section IV. Initially, the first choir sings the same pitches as those heard in the second choir at the work's opening, and later it sings the homophonic "a-i-ram" fragment-with its corresponding Bflat minor chord (27)-that was introduced by choir 2 in section I. Here, the first choir is acting as a memory of the second.

At the beginning of section $\mathrm{V}(28)$ the listener hears, for the first time, all seven voices contributing to the same spoken texture-a total alignment of musical layers. On the following page, Vivier again reverses the choirs' established roles: the first choir now provides a background of sustained chords for the more active second choir. Two measures later, the original roles are restored. Finally, a new interlocking relationship is established on page 33: text is shared between voices 1 and 4,2 and 5, and 3 and 6 as these voices move towards a unison B-flat. Although the six voices remain rhythmically independent, this technique creates a new relationship between the two choirs.

Another musical process, this time in the seventh voice, leads to the climax of the work. Beginning with the first sung eighth note in the last measure of 
page 32, there is a double process of growing durations for sung notes and diminishing durations for spoken text. Sung values increase: 1, 2, 3, 4, 5, 6 (in eighth notes), while durations for spoken text decrease: $8,7,6,5,4,3$. These last three words are distinct from the preceding spoken text-rather than rhythmically free, they are notated as strict eighth notes - and with their appearance they usher in a new section of music with a contrasting texture. This process in the seventh voice occurs as the other six voices of the ensemble are singing notes of increasing durations; it is as if the termination of the process in the seventh voice brings an end to the other processes while simultaneously acting as a signal for change.

Another durational musical process begins on page 36. The seven-voice homophonic chords have decreasing durations from chord to chord: 5, 4, 3, 2, 1 (in quarter notes). At the end of this process, voice 3 sings a solo and section $\mathrm{V}$ comes to a close.

In section VI, the two choirs return to their original roles: the second choir creates a sustained background for some active polyphony in choir 1 . The separation of these layers is reinforced by the avoidance of common pitches between the choirs. Towards the end of this section, a new process governs the durations for each note in melody 3 (voice 1). At first (54-55), durations increase: $3,4,5,6,7,8,9,14,15$ (in sixteenth notes, ignoring the grace notes), followed by one note that is ten sixteenth notes long. The durations then decrease from thirteen to six (56-58) then four to one sixteenth notes (59), at which point the last note (D-sharp) is accented and followed by a trill and a clear change in texture. A double process follows, controlling the second half of the florid melody in voice 1: the oscillations between $\mathrm{E}$ and $\mathrm{F}$ become slower, moving from sextuplets to quintuplets to sixteenth notes to triplets and finally to eighth notes, while the sustained notes between these oscillations gradually grow in duration from one to four quarter notes. Vivier closes section VI at the end of these simultaneous processes.

These observations make clear Vivier's use of musical processes to construct Chants, their relationship to musical layers, and their use as signals for formal change. Vivier plays with the layers' interaction as the piece progresses, effectively creating vivid, contrasting musical textures. After establishing the characters and roles of the two choirs, he has one influence the other, reverses their roles, and finally merges them to form a powerful tutti climax.

\section{Conclusion}

Melody is perhaps the single most important musical element in Vivier's compositional thinking during the composer's period of "purification," and Chants is an excellent example of a melody influencing an entire composition. Melody 1 guides everything from interval content and harmonic language to the development of secondary melodies and large-scale pitch organization. The tight relationships between Chants' three distinct melodies demonstrates Vivier's ability to spin out a surfeit of interrelated material from a single source. Chants also provides several lucid examples of Vivier's employment of musical layers 
with changing roles and relationships, and of signals to reinforce musical form-signals that go beyond the percussive, ritualistic examples of his mature works.

In such an early work, it is interesting to find that so much of Vivier's musical vocabulary is already established and incorporated into one composition. Many of the elements and techniques observed here are seen throughout Vivier's output: the use of linear processes and palindromes to govern durational structures, the expansion and contraction of pitch cells, the application of melodic properties to other musical elements, 5 the use of and play with musical layering, and the employment of both subtle and overt signals to signal change. When comparing, for example, the gradual expansion of musical cells in Chants with the gradual expansion of the main melody over the course of Vivier's orchestral work Siddhartha (Lesage 2008, 107), it is clear that the seeds for his masterpieces were already planted in this early work for small vocal ensemble.

\title{
REFERENCES
}

Lesage, Jean. 2008. "Claude Vivier, Siddharta, Karlheinz Stockhausen, la nouvelle simplicité, et le raga." Circuit 18 (3): 107-20.

Rhéaume, Martine. 2008. "Évolution d'un style musical-comment Vivier passé-t-il d'une oeuvre à l'autre?" Circuit 18 (3): 73-88.

—. 2009. "Stylistic Transitions in Vivier's Emergent Musical Style." British Postgraduate Musicology 10, http://britishpostgraduatemusicology.org/ bpm10/rheaume_martine-stylistic_transitions_in_viviers_emergent_ musical_style.pdf.

Vivier, Claude. 1975. Chants. Paris: Éditions Musicales Transatlantiques.

—_.1976. Siddhartha. New York: Boosey \& Hawkes.

.1977. Shiraz, pour piano. Montréal: Centre de Musique Canadienne.

_.1978. "Chants," in Nocturnales. Montréal: Université de Montréal Atelier de Musique Contemporaine.

Vivier, Claude, and Véronique Robert. 1991. "Les écrits de Claude Vivier." Circuit 2 (1): 39-136.

\begin{abstract}
Claude Vivier's Chants is considered by many to be his first significant musical composition, yet very little exploration has been undertaken to determine what techniques and ideas flow from this work into his mature musical style. This article provides an indepth analysis of Chants' pitch organization and the influence of the principal melody on the work as a whole, followed by an analysis of the manipulation of musical layers and the use of processes as signals for formal change in the work. These qualities bear strong similarities to Vivier's later works, demonstrating that Chants was pivotal in his development as a composer.
\end{abstract}

5 Vivier's application of minute melodic characteristics to small- and large-scale pitch organization in Chants is clearly influenced by Karlheinz Stockhausen's "formula" technique, first used in the latter's composition Mantra. Vivier studied with Stockhausen in 1972-74. 


\section{RÉSUMÉ}

L'œuvre de Claude Vivier intitulée Chants est considérée par beaucoup comme étant sa première œuvre importante. Toutefois, très peu d'études ont tenté de déterminer quelles techniques et quelles idées se sont transmises de cette œuvre à ses compositions plus tardives. Cet article présente une analyse approfondie de Chants du point de vue de l'organisation des hauteurs et de l'importance de la mélodie principale dans toute la composition. Cette analyse est suivie d'un examen de la manipulation des différentes couches musicales ainsi que de l'utilisation de certains procédés musicaux pour annoncer les changements formels de l'œuvre. L'auteur avance que ces caractéristiques se retrouvent de façon importante dans les œuvres ultérieures de Vivier, ce qui montre que Chants a bien été une œuvre cruciale dans le développement du compositeur. 